\title{
Penanaman Nilai-Nilai Pendidikan Agama Islam melalui Kegiatan Cinta Alam
}

\author{
Eko Saputro \\ SMK N 1 Magelang \\ Email: eko54@ymail.com
}

\begin{abstract}
Abstrak
Pemahaman siswa terhadap kegiatan cinta alam kabupaten SMA Negeri I Pabelan Semarang sangat rendah. Pemahaman mereka dalam partisipasi dalam kegiatan hanyalah untuk bersenang-senang. Hal ini disebabkan oleh beberapa faktor, salah satunya adalah kesadaran anak didik itu sendiri mengenai arti kegiatan organisasi cinta alam dan tujuannya hanya terbatas pada partisipasi rekreasi dan melarikan diri dari keluarga, jauh dari orang tua. Penanaman nilai-nilai pendidikan Islam melalui cinta alam SMU Negeri I Pabelan Kabupaten Semarang hanya memberikan materi tentang kegiatan petualangan atau olahraga petualangan di luar ruangan; hal ini disebabkan keterbatasan pengetahuan tentang nilai-nilai ajaran agama melalui cinta alam dan wacana di lingkungan Pembina. Faktor lain adalah latar belakang Pembina itu sendiri yang bukan anggota organisasi pecinta alam. Pembina tidak pernah berpartisipasi dalam pendidikan dasar tentang cinta alam dan petualangan.
\end{abstract}

The students understanding in the love nature activities of SMA Negeri I Pabelan Semarang district is very low. Their understanding in participation in the activities is merely for the fun. It is caused by several factors, one of which is a protégé of consciousness itself within the meaning of organizational activity love nature and purpose are limited to participation on refreshing and escape from family, away from the parents. Planting educational values of Islam through love of nature SMU Negeri I Pabelan Semarang District is just giving material about a credible form of adventure or adventurous sport outdoors; this is caused 
the limited knowledge about the values of religious teachings through love of nature and discourses on the environment of Trustees. The other factor is the background of Trustees itself rather than the organization or the nature lovers of Trustees has never participated in basic education about love the nature and adventure.

Kata kunci: nilai pendidikan Islam, cinta alam, Esspala

\section{Pendahuluan}

Manusia hanya akan menjadi manusia karena pendidikan, Mendidik berarti memanusiakan. Untk menjadi manusia briman, diperlukan pendidikan (Nawawi, 1993: 101). Menusia makhluk yang dapat dididik ssesuai dengan hakekatnya sebagai makhluk ciptaan Allah SWT, yang hidup sebagai makhluk individu dan sosialis di dalam masyarakat, karena mereka memiliki kemungkinan tumbuh dan berkembang di dalam keterbatasan dirinya sebagai manusia. Manusia adalah makhluk yang bereksistensi dia tidak sekedar ada tapi mengada, manusia adalah makhluk berfikir (homo sapiens) akal sebagai titik tolak. Orang sangat menjunjung tinggi akal, baik akal teoritis maupun praktis. Manusia menghasilkan pengetahuan dengan menggunakan akal yang dimilikinya dan manusia dapat berbuat baik dalam pengertian sempurna (Tim Dosen FIP-IKIP Malang, 1993: 101).

Pendidikan merupakan salah satu kunci sukses suatu bangsa, karena melalui pendidikan sumber daya manusia menjadi berkualitas. Dalam dunia pendidikan peran guru sangatlah pentng mereka mentransfer ilmu pengetahuan pada anak didik. Pendidikan memegang peranan penting bagi kelangsungan hidup manusia, sebab di sekolah 
tempat mencetak sumber daya manusia yang berkualitas dan diharapkan menjadi motor kemajuan dan kemakmuran bangsa.

Di dalam dunia pendidikan kurangnya pendidikan tentang lingkungan untuk ditanamkan bagi anak didik, sehingga anak didik kurang memahami arti pentingnya mempelajari ulmu-ilmu pengetahuan alam semesta ini serta memahami nilai-nilai dasar yang terkandung di dalamna, karena melihat manusia dengan alam saling membutuhkan dalam kesehariannya. Manusia ibarat barang tambang yang masingmasing memiliki grade quality, ada yang berupa emas, perak, dan perunggu, bahkan ada yang lebih rendah.

Sebagai grade quality-Nya Allah, Islam memandang alam dan manusia posisinya setara. Yang melebihi keduanya hanyalah Allah AlMuhiit, yang melampaui segalanya, yang memiliki segala hal di langit dan di bumi. Penanaman nilai-nilai pendidikan agama Islam serta memahami nilai-nilai alam semesta dalam agama, filsafar serta dalam pendidikan di sekolah kurang ditanamkan dalam aktivitas sehari-hari, sehingga banyak anak didik yan gtidkamemahami nilai-nilai melestarikan serta bertanggung jawab akan kelestarian alam semesta ini, karena melihat manusia mempunyai tanggung jawab sebagai khalifah di bumi (Maslikah, 2004: 1).

Agama merupakan pondasi bagi manusia dalam memahami segala aspek kehidupan di dunia ini, sumber di dalamnya sebagai pedoman untuk mencari, mengerjakan serta mendapatkan manfaat dalam menjalankannya. Kegiatan seperti mendalami nilai-nilai dasar melalui pelestarian alam bisa membangun jiwa kita sebagai khalifag fil'ardh 
atau tugas untuk menjaga kelestarian alam di muka bumi ini, kurangnya penanaman nilai-nilai pendidikan dalamkegiatan yang bergelut dalam bidang kecintaalaman atau pelestarian lingkungan hidup, yang dimana banyak anak didik yan gbelum bisa mengerti dan memahami nilai-nilai pendidikan agama Islam melalui kegiatan tersebut, dan kebanyakan mereka hanya mengikuti kegiatannya tapi belum mengerti dan memahami makna-makna serta nilai-nilai ajaran agama yang terkandung di dalamnya.

Penanaman nilai-nilai pendidikan agama Islam melalui kegiatan cinta alam di organisasi yang bergelut dibidang pecinta alammerupakan suatu wujud hubungan social melalui kehidupan bermasyarakat yang saling membutuhkansatu sama lainnya, bukannya dengan sumber daya alam yang begitu melimpah yang ada di bumi ini, manusia menjadi egois dan bahkan tidak peduli dengan kehidupan orang lain, mereka saling menguasai teknologi serta sumber daya alam di bumi ini dengan keegoisan. Ada beberapa permasalahan yang akan dijawab melalui kajian ini, yaitu: Seberapa jauhkan anak didik dalam memahami kegiatan cinta alam Esspala SMU Negeri 1 Pabelan Kabupaten Semarang tahun 2007, Adakah penenaman nilai-nilai pendidikan agama Islam melalui kegiatan cinta alam Esspala SMU Negeri 1 Pabelan Kabupaten Semarang tahun 2007 dan Seberapa jauhkan penanaman nilai-nilai pendidikan agama Islam pada anak didik melalui kegiatan cinta alam Esspala SMU Negeri 1 Pabelan Kabupaten Semarang tahun 2007. 


\section{Metode Penelitian}

Setelah data yang diperlukan terkumpul, maka langkah selanjutnya adalah menganalisa data yang telah terkumpul dengan menggunakan teknik deskriptif kualitatif, hal ini dimaksudkan untuk mengetahui tujuan-tujuan penelitian yang antara lain adalah sebaga berikut. Untuk mengetahui seberapa jauhkan anak didik dalam memahami kegiatan cinta alam Esspala SMU Negeri 1 Pabelan Kabupaten Semarang tahun 2007, untuk mengetahui adakah penenaman nilai-nilai pendidikan agama Islam melalui kegiatan cinta alam Esspala SMU Negeri 1 Pabelan Kabupaten Semarang tahun 2007 dan Untuk mengetahui seberapa jauhkan penanaman nilai-nilai pendidikan agama Islam pada anak didik melalui kegiatan cinta alam Esspala SMU Negeri 1 Pabelan Kabupaten Semarang tahun 2007.

\section{Pembahasan}

\section{Penanaman Nilai Pendidikan Agama Islam pada Anak}

Penanaman nilai keimanan dan cinta alam pengertian mendasar dari nilai akan dikemukakan menurut Milton Research dan James Bank (dalam Thaha, 1996: 60), nilai adalah:

"Suatu tipe kepercayaan yang berada dalam ruang lingkup system kepercayaan yang mana seseorang bertindak atau mengkindari suatu tindakan, atau mengenal sesuatu yang pantas atau tidak pantas dikerjakan. Dari pengertian tersebut dapat dipahami bahwa nilai merupakan sifat yang melekat pada sesuatu (sistem kepercayaan) yang telah berhubungan dengan subjek yang memberi arti (yakni manusia yang meyakini)." 
Dalam kamus besar bahasa Indonesia nilai mempunyai arti sifatsifat (hal-hal) yang penting atau berguna bagi kemanusiaan (Depdikbud, 1994: 714). Sedang pengertian keimanan meliputi: Iman menurut pengertian yang sesungguhnya ialah kepercayaan yang meresap kedalamhati, dengan penuh keyakinan, tidak bercampur syak dan ragu. Serta member pengaruh bagi pandangan hidup, tingkah laku dan perbuatan sehari-hari. Jadi, iman itu bukan semata-mata ucapan lidah, bukan sekedar perbuatan dan bukan pula hanya merupakan pengetahuan tentang rukun iman. Sesungguhnya iman itu bukan semata-mata pernyataan seseorang dengan lidahnya, bahwa dia orang beriman (mukmin), karena banyak pula orang munafik (beriman palsu) (AlQardhawy, 1983: 25).

Pengelolaan lingkungan hidup adalah dalam kehidupan, wawasan hidup seseorang,yakni sebuah gagasan, sikap, dan cita-cita hidupnya akan terwujud apabila memiliki ketahanan hidup yakni kemampuan ketangguhan untuk menjamin kelangsungan hidup yang jaya, sejahtera, dan bahagia di dalam suatu usaha pengelolaan hidup yang serasi, seimbang dan selaras dalam hubungannya dengan Tuhan, manusia dan sumber daya alam disekitarnya (Soerjani dkk, 1987: 256).

Ilmu adalah lukisan atau keterangan lengkap dan konsistensi tentang fakta pengalaman dengan istilah-istilah yang sedikit atau sederhana mungkin. Ilmu adalah pengetahuan yang berasal dari pengamatan, studi dan pengalaman yang disusun dalam satu system untu menentukan hakikat dan prinsip-prinsip tentang hal yang sedang dipelajari. 
Meletakkan pola dasar pendidikan Islam di setiap perilaku nilainilai Islami yang member ruang lingkup keagamaan. Nilai disini yang dimaksud adalah nilai yang diajarkan didasarkan pada ajaran Islam. Maka sejauh mana pemahaman seorang guru terhadap ajaran Islam, sejauh mana pula penggunaan materi yang disampaikan kepada anak didik, dan sejauh itu pula ajaran agama Islam sebagai sumber nilai. Pendidikan agama Islam adalah usaha berupa bimbingan terhadap anak didik, agar kelak setelah selesai pendidikannya dapat memahami dan mengamalkan ajaran-ajarn Islam serta menjadikannya way of life (jalan kehidupan).

Nilai-nilai pendidikan Islam disetiap perilaku, berarti melahirkan nilai-nilai Islami yang memberi ruang lingkup keagamaan. Nilai disini yang dimaksud adalah nilai yang diajarkan di dasarkan pada ajaran Islam. Maka sejauh mana pemahaman dari seorang guru terhadap ajaran agama Islam, dan sejauh itu pula penggunaan materi yang disampaikan kepada anak didik, dan sejauh itu pula ajaran agama Islam sebagai sumber nilai.

Dalam pendidikan, untuk mencapai tujuan pendidikan yang bermutu, maka harus memilih nilai-nilai yang dipandang perlu bagi perkembagnan anak (murid). Guru berperan sebagai pemilih dan penentu nilai yang akan diterapkan dalam pendidikan di dalam dan pendidikan diluar sekolah, seperti pendidikan melalui kegiatan cinta alam.

Adapun macam-macam nilai yang terdapat dalam kegiatan cinta alam di sekolah antara lain nilai materi, kepedulian, estetika, spiritual, sosial. Nilai Materi adalah Menanamkan materi-materi yang mencakup tentang lingkungan hidup pada anak; nilai Kepedulian adalah sebagai 
rasa kepedulian kita akan kelestarian alam; nilai estetika adalah mempelajari ilmu-ilmu tentang pengetahuan alam yang ada di bumi ini sebagai wawasan tentang ilmu alam; nilai spiritual adalah nilai tentang keimanan manusia akan alam sebagai ciptaan Allah SWT, karena keberhasilan adalah sebagian dari iman; nilai Sosial adalah upaya untuk memanfaatkan serta melestarikan sumber daya alam dengan seksama atau dalam artian untuk menggunakan sumber daya alam dengan sebaikbaiknya untuk kepentingan bersama manusia lainnya.

\section{Hubungan dari nilai-nilai}

Hubungan nilai materi dengan nilai kepedulian adalah mempraktekkan materi-materi pelajaran tentang ilmu-ilmu alam yang telah dipelajari sebgai rasa kepedulaian kita sebagai manusia untuk melestarikan alam. Hubungan dari nilai kepedulian dengan nilai estetika adalah mempelajari ilmu-ilmu tentang estetika atau mempelajari ilmuilmu tentang pengetahuan alam karena dengan rasa kepedulian ini manusia ingin mencari pengetahuan mengenai kehidupan yang terjadi di alam semesta ini. Hubungan dari nilai estetika dengan nilai spiritual adalah sebagai rasa keimanan dan keyakinan bahwa apa-apa yang terdapat di alam kehidupan ini adalah ciptaan Allah SWT, dan manusia sebagai abdi Tuhan bertugas untuk melestaikan dan bertangung jawab akan kelestarian alam. Hubungan dari nilai estetika dengan nilai sosial adalah bahwasannya kita sebagai manusia berupaya untuk mempelajari ilmu tentang estetika atau ilmu tentang alam, yang dimana ktia mempelajarinya dengan orang lain, dan tujuan dari mempelajari ilmu 
estetika ini karena manusia mempunyai daya pikir untuk mempelajari hal-hal yang terjadi di bumi ini dengan keterbatasan daya pikirannya dan ketika manusia kemampuan berpikirnya sudah terbatas maka manusia meyakini semuanya hanyalah Dia Allah SWT.

\section{Penanaman Nilai Ibadah dan Cinta Alam}

Menurut ajaran Islam fungsi dasar manusia beribadah, yang memiliki konsep pengertian lebih luas dibanding dengan mengabdi atau melayani. Setiap muslim selalu berfikir bahwa beribadah adalahkepatuhan kepada Allah di dalam segala segi kehidupan, ibadah bukan hanya berarti shalat, berpuasa, memberi zakat, dan melaksanakan haji saja, tetapi juga semua aspek kehidupan, seperti: makan, tidur, belajar, memperlajari alam semesta, penyelidikan ilmuah, berusaha melakukan kegiatan olahraga dan pengetahuan termasuk didalammnya juga adalah mencarinafkah bagi keperluan hidup kelaurga, semua upaya dan kegiatan manusia, sepanjang diniatkan untuk mencari keridhaan Allah, maka hal tersebut dinamai ibadah (Al-Buraey, 1986: 114-115).

Allah mengirim wahyu petunjuk untuk mengaktifkan akal pikir manusia dan meluruskan imannya serta pedoman dalamberibadah melalui kitab-kitab suci yang dibawa oleh para nabi dan Rasul-Nya. Di dalam Al-Qur'an, manusia diperintahkan untuk mempelajari alam semesta secara ilmiah dan memanfaatkan-Nya sebagai sarana ibadah serta pemenuhan bagi keperluan dan kesejahteraan hidupnya.

Untuk maksud itu manusia diwajibkan menggunakan akal pikir dan iman secara terpadu sehingga dapat terhindar dari bahaya 
keangkaramurkaan hawa nafsu dan keserakahan yang dapat menhancurkan dirinya sendiri.

Penanaman nilai ibadah dan cinta alam dalam penelitian ini adalah bagaimana perilaku keimanan anak didik sesuai dengantuntutan agama sebagai berikut: Taat dan melaksanakan ibadah, membiasakan untuk selalu menjaga kebersihan, rajin mengikuti kegiatan sosial kemasyarakatan, dan bergaul dengan baik terhadap sesama manusia.

Manusia adalah sejenis makhluk hidup, karena itu manusia juga berinteraksi dengan alam lingkungannya. Manusia memperngaruhi lingklugnan hidupnya, atau ide juga mengusahakan sumber daya alam lingkungannya unutk mempertahankan jenisnya, dan sebaliknya manusia dipengaruhi oleh lingkungannya. Tidak berbeda dengan organisme/makhluk hidup lainnya, manusia bersama dengan lingkungan hidupnya merupakan suatu ekosistem (Resosoedarmo dkk, 1985: 197).

Di samping itu kelakuan dan tingkat kebudayaan manusia sangat ikut menentukan bentuk danintensitas interaksi antara manusia dan alam lingkungannya. Di dalam kesatuan ekosistem, kedudukan manusia adalah sebagai bagian dari unsur-unsur lain yang tidak mungkin terpisahkan. Karena itu seperti halnya dengan organisme lainnya, kelangsungan hidup manusia tergantung pula pada kelestarian ekosistemnya. Untuk menjaga terjaminnya kelestarian ekosistem, faktor manusia adalah sangat dominan. Manusia harus dapt menjaga keserasian hubungan timbal balik antara manusia dengan lingkungannya, sehingga keseimbangan ekosistem, faktor manusia adalah sangat dominan. Manusia harus dapatmenjaga keserasian hubungan timbal balik antara manusia dengan 
lingkungannya, sehingga keseimbangan ekosistem tidak terganggu. Pengaruh manusia terhadap lingkungannya dapat mengakibatkan tiga kemungkinan kepada tiga kemungkinan kepada kualitas lingkungannya, yaitu deteriorasi, tetap lestari, dan memperbaharui.

\section{Penanaman Rasa Cinta Alam pada Anak Pendidikan Kepecintaalaman}

Bertumpuknya peroalan lingkungan hidup yang ada di bumi tempat kita berpijak, telah menimbulkan keprihatinan sendiri terhadap nasib bumi ini dan seluruh penghubinya. Akan sekedar prihatin, mengutuk, menyesali saja tidaklah cukup dan tidak akan merubah keadan. Oleh karenanya, pendidikan yan gmencoba menyadarkan anak didik melalui kepedulian terhadap lingkungan hidup yang berkutat dengan wacanawacana tentang lingkungan hidup yang memenuhi isi kepala dari anak didik.

Seiring dengan proses industrialisasi yang pesat dalam tubuh kapitalisme yang dianut oleh mayoritas negara-negara yang ada di muka bumi ini, termasuk Indonesia, kerusakan alam terjadi dengan begitu cepatnya. Kelangsungan hidup para penghuni bumi telah dikalahkan oleh kepentingan segelintir orang kaum pemiliki modal yang berkuasa diatas penderitaan jutaan manusia, yang terus menerus mengejar keuntungan dar ihasil mengeruk kekayaan alam. Tujuan sesaat dari para penguasa ini ternyata juga telah merasuki pikiran banyak orang (mungkin juga kita). Kita sering hanya memikirkan apa yang akan kita dapat hari ini. Kita 
tidak pernah melihat apa yang akan kita hadapi di masa depan, jika alam dan lingkungan hidup kita hancurkan untuk kepentingan hari ini.

Sistem Pendidikan yang digunakan untuk menghasilkan manusia unggul meliputi: Pemberian porsi yang memadai kepada pendidikan agama, etika, dan moral agar mampu mewarnai pola pikir dan pola tindak para peserta didik. Memperhatikan, memanfaarkan, dan mengembangkan indigeneous knowledge, agar mampu menghasilkan IPTEK dan pola pemanfaatan sumber daya alam serta sistem sosial budaya yang akrab dan sesuai dengan kebutuhan dan kondisi lingkugnan lokal. Penerapan konsep pendidikan seumur hidup (life long education) yang mengikutsertakan dunia usaha dalam pemberdayaan sumber daya manusia melalui pelatihan di lingkungan kerja berdasarkan undangundang. Peningkatan mutu proses pendidikan yang menekankan kemandirian peserta pendidikan untuk bertindak kreatif dan kritis terhadap keberlanjutan pembangunan di dalam keluarga bangsa danbangsa-bangsa yang beraneka ragam kebudayaan dan agamanya tetapi dipersatukan oleh kemanusiaan yang universal yang menjunjung hak-hak asasi kemanusiaa di dalam negara hukum. Desentralisasi, individualisasi, dan kastomiassi proses pendidikan (individualized and customized education) untuk menghasilkan luaran pendidikan yang sesuai dengan kebutuhan lokal, berperan aktif dalam pembentukan dan pengembangan identitas masyarakat lkal lingkungan, yang diperlukan bagi pengembangan manusia unggul adalah lingkungan yang memiliki kondisi sosial-politik, sosial-ekonomi, dan sosial-budaya yang kondusif 
yang didukung oleh sistem hukum yang responsif dan sistem hankam yang tangguh.

\section{Aksi Lingkungan}

Ada beberapa metode yang dapat dipergunakan untuk mendidik anak dalam rangka penanaman rasa cinta alam dengan aksi lingkungan pada anak didik, yaitu antara lain:

\section{Metode Praktek}

Metode praktek atau belajar dengan praktek kadalah salah satu diantara metode mutakhir yang diserukan oleh pendidikan modern. Maka pendidikan Islam bukan diberikan secara teori saja, akan tetapi dilakukan pula dengan cara praktek. Pembentukan akhlak dan rohani seseorang tidaklah cukup dengan sekedar nasehat, tetapi memerlukan praktek knyata, sehingga akhlak mulia dapat terbentuk dalam pribadinya dan hubungan yang harmonis sesama manusia dapat terjalin dengan baik (AlJamali, 1986: 75).

Dalam metode praktek anak didik dituntut untuk mempraktekan ajaran-ajaran yang telah diperolehnya daro pelajaran tentang lingkungan, dan harapan dari pendidik bisa terciptanya manusia-manusia yang benarbenar bisa melestarikan lingkungan. Dari metode ini diharapkan nantinya anak didik bisa mempraktekan dari teori-teori yang telah diajarkan melalui pendidikan dan bisa menjadi modal untuk disosialisasikan dalam kehidupan di masyarakat. 
Dari metode ini, maka ada beberapa hal yang harus dilakukan dalam pembangunan koalisi kita. Aktivitas koalisi harus selslu menggabungkan antara teori dengan praktek, karena teori tanpa praktek adalah onani, dan praktek tanpa teori adalah aborsi.

\section{Metode Bimbingan}

Membimbing dalam artian mengarahkan anak dan sebagai acuan dalam pembahasan tentang bimbingan dalam memahami nilai-nilai pendidikan yang terkandung dalam kegiatan cinta alam serta kaitannya dengan kemampuan siswa menyesuaikan diri di sekolah dan di alam bebas, perlu penulis kemukakan beberapa batasan pengertiannya:

Menurut Prajitno pengertian bimbingan sebagai berikut: Bimbingan merupakan bantuan yang diberikan kepada siswa dalam rangka upaya menemukan pribadi mengenal lingkungan dan merencanakan masa depan (Prayitno, Dkk, 1998: 23).Bimbingan dalam konteks di atas lebih merujuk pada upaya membantu anak untuk menjadi manusia yang dewasa dalam pengertian luas, dalam arti tidak dibatasi dalam bidangbidang tertentu dan tidak didasarkan timbulnya kesulitan pada diri anak.

Menurut pendapat Miller: Bimbingan adalah proses bantuan terhadap individu untuk mencnapai penanaman diri dan pengarahan diri yang dibutuhkan untuk melakukan penyesuaian diri secara maksimum kepada sekolah, keluarga, serta masyarakat (Sulaeman, 1978: 3).

Membimbing anak dalam memahami nilai-nilai pendidikan agama Islam melalui kegiatan cinta alam merupakan bimbingan anak didik 
dalam pengarahan serta penyuluhan yang lebih baik kepsikologis bagi anak didik.

\section{Metode Penyadaran}

Manusia merupakan makhluk ciptaan Allah yang dibekali dengan berbagai potensi fitrah yang tidak dimiliki makhluk lainnya. Potensi istimewa ini dimaksudkan agar manusia dapat mengemban dua tugas utama, yaitu sebagai khalifatullah di muka bumi dan juga abdi Allah untk beribadah kepada-Nya.

Manusia dengan berbagai potensi tersebut membutuhkan suatu proses pendidikan, sehingga sehingga apa yang akan diembannya dapat terwujud. Pendidikan memiliki hubungan yang sangat erat dengan psikologi. Pendidikan merupakan suatu proses panjang untuk mengaktualkan seluruh potensi diri manusia sehingga potensi kemanusiaannya menjadi aktual. Dalam proses mengaktualisasi diri tersebut diperlukan pengetahuan tentang keberadaan potensi, situasi dan kondisi lingkungan yang tepat untuk mengnaktualisasikannya. Pengetahuan tentang diri manusia dengan segenap permasalahannya akan dibicarakan dalam psikologi umum. Dalam hal pendidikan Islam yang dibutuhkan psikologi Islami, karena manusia memiliki potensi luhur, yaitu fitrah dan ruh yang tidak terjamah dalam psikologi umum (Barat).

Berdasarkan uraian diatas, maka sudah selayaknya dalam pendidikan Islam memiliki landasan psikologis yang berwawasan kepada Isalam,dalam hal ini dengan berpadu kepada Al-Quran dan Hadits sebagai sumbernya, sehingga akhir dari tujuan pendidikan Islam dapat 
terwujud dan menciptakan insan kamil bahagia di dunia dan akhirta, serta berupaya senantiasa mengarahkan manusia agar senantiasa menjaga kelesatarian alam di muka bumi ini.

Menanamkan kesadaran memang tidak begitu mudah, tetapi usaha yang membangun agar anak didik bisa sadar dan peduli akan lingkungan hidup bisa sadar dan peduli akan lingkungan hidup bisa melalui gerakangerakan seperti berikut ini: Melakukan pendidika lingkungan hidup, pendidikan ini dilakukan secara sistematis dan berkelanjutan untuk memperdalampemahaman terhadap berbagai persoalan lingkungan, serta meningkatkan kesadaran dan komitmen. Kurikulum dan metode pendidikannya disesuaikan dengan kondisi obyektif yang tentunya terus berkembang. Melakukan diskusi teori-teori tentang lingkungan, ini penting agar tidak terjadi kedogmatisan, sehingga pengetahuan aktivis lingkungan semakin bertambah, dan melakukan aksi tentang lingkungan, menanam pohon (penghijauan), membuang sampah pada tempatnya, menjaga kebersihan lingkungan sekitar dan menyadarkan agar selalu melesatarikan alam.

Air, tanah, tumbuh-tumbuhan, hewan, dan udara adalah bagian dari isi bumi atau sumber daya alam untuk kehidupan manusia, Tuhan menciptakan bumi dan seisinya untuk memfasilitasi kebutuhan manusia dalam menjalankan aktivitas kehidupan sehari-hari dimuka bumi ini dan manusia diciptakan di planet bumi untuk menjaga serta memanfaatkan sumber daya alam dengan manusia lainnya agar digunakan sebaikbaiknya. 
Di Negara Indonesia sumber daya alam begitu melimpah dan telah diatur dalam Undang-Undang Dasar 1945 pasal 33 ayat 3 yang berbunyi: kekayaan alam diseluruh Indonesia dikuasai oleh negara serta digunakan dan dimanfaatkan sebaik-baiknya untuk kemakmuran dankebutuhan hajat hidup orang banyak di seluruh Negara Kesatuan Rebuplik Indonesia (NKRI).

Apakah undang-undang yang mengatur tentang lingkungan bisa dijadikan sebagai landasan hukum ataukah sebagai simbolik atau sebagai alat pemanfaatan sumber daya alam bagi orang-orang yang mempunyai kepentingan untuk menguras habis sumber daya alam di seluruh Negara Indonesia. Melihat kerusakan alam yang semakin menjadi-jadi di negara Indonesia yang menyebabkan banjir bandang, tanah longsor, limbah pabrik yang sudah tidak bisa ditolerir lagi karena pembuangannya di sungai-sungai yang menyebabkan bau tidak sedap, panyakit kulit yang berimbas kepada manusia dan kerusakan sumber daya air serta lingkungan disekitarnya.

Banjir yang menenggelamkan beberapa kota di Indonesia pada musim hujan tahun ini misalnya, merupakan indikasi ketidakseimbangan siklus hidrologi. Penebagnan beberapa vegetasi tanaman dan penggungulan hutan di daerah hulu sebagai penahan aliran air hujan meningkat yang mengakibatkan turunya laju resapan air ke dalam tanah sehinga volume air larian atau limpasan meningkat maka terjadilah banjir.

Penggundulan hutan nyang sering terjadi juga mempengeruhi terhadap kelangkaan air, ini mulai nampak pada daerah-daerah yang 
langka air pada saat musim kemarau, pada dasarnya kelangkaan air yang terjadi bukan karena volume air di bumi berkurang atau menyusut karena air mengikuti hukum kekelan massa (tidak dapat berkurang maupun bertambah). Oleh karena itu dalam daur air (siklus hidrologi) jumlah air statis. Tapi seperti telah dijelaskan d atas bahwa resapan air yang masuk ke dalam tanah pada musim penghujan sebagai mata air relatif sedikit akibatnya debit air dari mata airpun sedikit.

"Water for life" (air sebagai sumber kehidupan), tema ini agaknya tepat untuk diangkat sebagai tema utama untuk bumi disamping tematema yang lain, mengingat kelesarian sumber daya air semakin terancam kritis, baik dari segi kualitas maupun kuantitasnya. Krisis air yang terjadi tak lepas dari ulah manusia sebagai peran utama dalam kehidupan, walaupun juga ada faktor lain penyebab krisis air. Tapi prosentase ini lebih kecil dibanding aktivitas manusia yang eksploratif.

Manusia diciptakan oleh Tuhan di planet bumi ini untuk menjaga serta memanfaatkan sumber daya dalam dengan keadilan serta sebaikbaiknya agar kelestarian sumber daya alam di planet bumi bisa dipertahankan.

\section{Peranan Nilai-Nilai Pendidikan Agama Islam melalui Cinta Alam pada Anak}

\section{Pendidikan Keagamaan}

Kepercayaan Keagamaan berasal dari kata "agama" yaitu prinsip kepada Tuhan dengan aturan-aturan syariah tertentu (Kamus, hlm 22). Sedangkan keberagamaan berarti sifat yang berhubungan dengan agama. 
Pandangan Islam Tentang Alam dan Manusia. Manusia adalah makhluk Allah SWT yang terdiri dari kesatuan unsur jasmani dan rohani, manusia diciptakan oleh Allah SWT tidak lain bertugas untuk menyembah dan mengelola serta kemakmuran bumi agar manusia dapat hidup sejahtera lahir dan batin.

Untuk mengemban tugas-tugas tersebut, manusia diberi status yang terhormat yaitu sebagi khalifah di bumi, lengkap dengan kerangka dan program kerjanya, secara simbolis fungsi dan kerangka kerja itu dinyatakan Allah SWT pada proses penciptaan Adam AS:

Sesungguhnya aku hendak menjadikan seorang khalifah di muka bumi (Qs. 2: 39). Dan sekaligus menegaskan manusia untuk memakmurkan bumi (Qs. 11: 61).

Menurut ajaran Islam fungsi dasar manusia beribadah yang memiliki konsep pengertian lebih luas dibanding dengan mengabdi atau melayani. Setiap muslim selalu berfikir bahwa beribadah adalah kepatuhan kepada Allah di dalam segala segi kehidupan, ibadah bukan hanya berarti shalat, berpuasa,memberi zakat, dan melaksanakan haji saja, tetapi juga semua aspek kehidupan, seperti makan, tidur, belajar, mempelajari alam semesta, penyelidikan ilmiah, berusaha melakukan kegiatan olahraga dan pengetahuan termasuk di dalamnya juga adalah mencari nafkah bagi keperluan hidup keluarga, semua upaya dan kegiatan manusia, sepanjang diniatkan untuk mencari keridhaan Allah maka hal tersebut dinamai ibadah (Al-Buraey, 1986: 114-115).

al-Quran sendiri menyatakan bahwa tujuan penciptaan manusia dan jin di jagad raya ini, semata-mta hanya untuk beribadah kepada-Nya. 
Manusia lebih luhur dibanding Jin, dan diangkat sebagai khalifah (wakil) Allah di muka bumi. Tugas sebagai wakil Allah ini bukanlah monopoli para Rasul dan Nabi yang memang dikirim untuk menuntun manusia, atau juga bukan hanya untuk raja, gubernur, atau pejabat tinggi yang dipilih atau ditunjuk untuk mengurus persoalan bahasannya, ini adalah misi yang dibebankan bagi semua manusia. Setiap pribadi bertanggung jawab bagi manusia dan makhluk lain yang ada dalam lingkup pengaruhnya.

Salah satu implikasi terpenting dari kekhalifahan manusia di muka bumi ini adalah pentingnya kemampuan unutk memahami alam semesta tempat ia hidup dan menjalankan tugasnya. Manusia memiliki kemungkinan untuk hal itu dikarenakan kepadanya dianugerahi Allah berbagai potensi yang tekandung. Disamping itu, alam semesta ini beserta apa-apa yang ada di dalamnya adalah ciptaan Allah SWT untuk kepentingan umat manusia secara keseluruhan.

Dengan menjalankan perintah-Nya dan menjauhi larangan-Nya, manusia telah mengerjakan tugasnya hidup di dunia dan melaksanakan tujuan-tujuan Allah yang telah menciptakan manusia hidup di bumi ini. Karena manusia adalah makhluk yang termulia di bumi ini, maka segala sesuatu memang disediakan untuknya diantara tugas sekunder manusia, yaitu memanfaatkan alam dan tenaga yang dikandungnya guna memenuhi keperluan dan kebutuhannya serta teman-temannya.

Hubungan manusia terhadap alam adalah sebagai pemanfaat, dan bukan sebagai saingan, disamping tugas manusia yaitu beribadah, dan tugas sekundernya adalah memanfaatkan alam, maka tugas manusia yang 
lain adalah bekerja, mengajar dan belajar, mewujudkan keadilan, memerintah sesuai dengan hukum Allah, dan bertindak sebagai wakilnya di muka bumi. Misalnya, Islam mengajak manusia untuk menggunakansumber daya materi dan insani semata-mata untuk melahirkan keadilan, kebijakanndan perdamaian, yang membuat pelaksanaan gunsinya menjadi mudah.

\section{Analisis data tentang anak didik dalam memahami kegiatan cinta alam Esspala SMU Negeri 1 Pabelan Kabupaten Semarang tahun 2007}

Menanamkan materi-materi pendidikan agama Islam berbarti, mendidik anak untuk memahami nilai-nilai agama, semisal agama mengajarkan tentang akidah akhlak kita tentang kebersihan badan, kingkungan dan melestarikan alam semesta.

Namun hasil dari penelitian menunjukkan bahwa sejauh ini pemahaman anak didik mengikuti kegiatan cinta alam Esspala SMU Negeri 1 Pabelan Kabupaten Semarang tahun 2007 sanatlah rendah, karena adanya berbagai faktor yang menjadi kendala anak didik dalam memahami makna mengikuti kegiatan cinta alam.

Faktor-faktor ataupun kendala yang ada pada anak didik dalam memahami kegiatan cinta alam Esspala adalah sebagai berikut: Dari faktor kesadaran anak didik untuk benar-benar aktif di dalam organisasi cinta alam rendah, karena survey membuktikan banyak anak didik yang sudah mengikuti pendidikan dasar Esspala tidak aktif lagi di organisasi Esspala. Kebanyakan anak didik memahami bahwa kegiatan cinta alam 
Esspala hanya sekedar bersenang-senang saja, kemah, wisata dan bermain-main di gunung. Hampir $60 \%$ anak didik Esspala mempunyai problem kasih sayang dari orang tua, karena mayoritas orang tua mereka bekerja di luar kota bahkan keluar negeri. Jadi keberadaannya atau keikutsertaannya di organisasi cinta alam Esspala hanya sekedar buat pelarian untuk bersenang-senang dengan teman-teman yang ada di organisasi Esspala.

Jadi selama ini anak didik dalam memahami cinta alam sangat rendah, melihat hasil observasi dan interview yang diperoleh di lapangan peneliti. namun ada sekitar $40 \%$ anak yang memahami keikutsertaan dalam kegiatan cinta alam, yang dimana mereka menyadari bahwa kegiatan cinta alam adalah sebagai wujud rasa syukur akan ciptaan alam oleh Allah SWT.

Jadi, makna-makna yang terkandung di dalam kegiatan cinta alam tentang pelestarian alam sebagai tugas kita sebagai manusia yaitu: untuk abdi Tuhan, sebagai ajaran dan perintah dari ayat suci al-Qur'an. dan utuk memanfaatkan serta melestarikannya bersama semua manusia di bumi ini. ibadah bukan hanya zakat, shalat, sodaqoh, puasa, dan naik haji saja tetapi ibadah bisa melalui olah raga dan kegiatan alam bebas. didalam pendidikan ajaran agama Islam, ibadah juga bisa melalui kegiatan olahraga alam bebas, karena ini merupakan dari nilai rasa syukur akan ciptaan Tuhan (Al-Buraey, 1986: 114-115). 


\section{Analisis data tentang adakah penanaman nilai-nilai pendidikan agama Islam melalui kegiatan cinta alam Esspala SMU Negeri 1 Pabelan Kabupaten Semarang tahun 2007}

Berdasarkan hasil pengelolaan data dari observasi di lapangan mengenai sejauh mana penanaman nilai-nilai pendidikan agama Islam pada anak didik melalui kegiatan cinta alam Esspala SMU Negeri I Pabelan Kabupaten Semarang sangatlah rendah, karena dari pemaparan oleh Pembina Esspala yang berinisial Sp, menuturkan bahwa, penanaman nilai-nilai pendidikan agama Islam pada anak didik dalam mengikuti kegiatan cinta alam Esspala sangatah rendah, karena adanya beberapa faktor yang mempengaruhi dari pembina Esspala. namun, dari Pembina sendiri pernah menjelaskan tentang makna-makna di dalam kegiatn cinta alam, yaitu sebagai rasa syukur akan ciptaan Tuhan dan rasa kepedulian kita sebagai manusia yang selalu membutuhkan sumber daya alam (SDA) sebagai sumber kehidupan kita sehari-hari dan kita juga penduli terhadap kelestarian alam. Namun dari usaha pembina sendiri dalam penanaman nilai-nilai pendidikan agama Islam pada anak didik ada beberapa faktor yang menjadi kendala dalam penanamannya.

Faktor-faktor penghambat dari penanaman nilai-nilai pendidikanagama Islam melalui kegiatan cinta alam yang sangat rendah adalah sebagai berikut: Kurangnya penguasaan wacana-wacana dari Pembina mengenai makna-makna yang terkandung di dalam kegiatan cinta alam, sehingga dari pembina sendiri hanya mampu memberikan materi-materi dasar tentang kepetualangan, semisal mountenering, susur gua, dan olahraga alam bebas, panjat tebing dan bermain tali. Melihat 
latar belakang Pembina Esspala sendiri bujan dari organisasi cinta alam, sehingga bekal yang dibawa dalam membimbing siswa-siswi hanya materi-materi tentang alam bebas.

Namun dari wacana tentang lingkungan, dari Pembina yang berinisial Sp, menuturkan: bahwa, dari tujuan organisasi Esspala sendiri adalah menciptakan manusia-manusia yang peduli akan kelestarian sumber daya alam sebagai abdi Tuhan. dan dari kegiatan Esspala dari Pembina pernah mendidik para siswa-siswi Esspala untuk melakukan aksi-aksi tentang pengelolaan lingkungan atau kegiatan tentang kecintaalaman. semisal, bersih-bersih sampah disekitar sekolah, penghijauan atau penanaman pohon, sampai mengenalkan nama-nama pohon sampai tumbuh-tumbuhan di sekitar sekolah/ tetapi dari kegiatan tersebut adalah suatu pengabdian kepada Tuhan Yang Maha Esa.

Menanamkan nilai sosial pada anak berarti, mendidik anak untuk melestarikan alam sebagai wujud nilai sosial, karena kita diperintahkan di dalam ajaranagama bahwa, tuhan menciptakan alam semesta untuk dimanfaatkan serta dikelola oleh semua manusia tanpa adanya saingan satu sama lainnya.

Namun dari penhelasan mengenai nilai-nilai pendidikan Agama Islam semisal, nilai keimanan yang terkandung di dalam kegiatan cinta alam pada anak kurang disinggung oleh Pembina, karena keterbatasan akan ilmu pengetahuan dan wawasan akan sumber-sumber nilai-nilai pendidikan yang diajarkan oleh agama. 


\section{Analisis data tentang seberapa jauhkah penanaman nilai-nilai pendidikan agama Islam melalui kegiatan cinta alam Esspala SMU Negeri 1 Pabelan Kabupaten Semarang tahun 2007}

Nilai-nilai agama melalui kegiatan cinta alam adalah nilai anjuran untuk melestarikan alam, nilai pelerstarian alam, nilai syukur akan ciptaan Tuhan Yang Maha Esa.

Upaya menyadarkan manusia untuk bertanggung jawab akan kelestarian alam sebagai abdi Tuhan atau sebagai khalifah di bumi adalah sesuai dengan anjuran ayat suci Al-Quran. Dan sejauh ini dari data yang diperoleh dari penelitian dan interview dilapangan, survey membuktikan bahwa penanaman nilai-nilai pendidikan agama Islam melalui kegiatan cinta alam adalah dengan megnadakanaksi-aksi lingkungan yangsudah dilakukan bersma-sama siswa-siswi Esspala dan Pembina Esspala, semisal dengan megnadakanpelestarian alam dengan penhijauan kembali tanah-tanah yang mulai gersang karena tidak adanya pohon yang tumbuh di atasnya, menyadarkan anak didik untuk memahami makna-makna dalam ajaran keagamaan, semisal menyadarkan anak didik bahwa wujud dari kegiatan cinta alam sebagai wujud nilai keimanan akan kebersihan danrasa syukur akan ciptaan alam oleh Allah SWT.

Dari hasil penanaman nilai-nilai pendidikan agama Islam melalui kegiatan cinta alam, sejauh ini diketahui bahwa terdapat nilai-nilai sosial melalui kegiatan penghijauan yang dimana, dengan penghijauan berarti telah terdapat nilai sosial, yaitu bersama-sama dengan manusia lainnya anak didik telah berusaha untuk mengelola dan melestarikan alam dengan tanpa sebuah persiangan dengan manusia lainnya, mengingat dalam 
ajaran keagaman ita hidup di alam semesta ini adalah untuk mengelola dan memanfaatkan sumber daya alam (SDA) dengan bersama-sama manusia lainnya tanpa adanya persaignan dan keegoisan.

Untuk mengajarkan anak didik supaya memahami danmempelajari ayat-ayat tentang manusia sebagai khalifah di bumi yang mempunyai peranan pentign untuk mengelola serta memanfaatkan sumber daya alam dengan sebaik-baik mungkin dan tanpa keserakahan, dan di dalam tujuan pendidikan Islam salah satunya adalah untuk memahami nilai-nilai agama dalam kegiatan cinta alam, ini merupakan tujuan dari pendidikan Islam.

Menanamkan nilai-nilai pendidikan agama Islam diperlukannya metode-metode dalam proses belajar agar suatu sistem pembelajaran dapat terciptanya tujuan pendidikan yang diinginkan. dalam pendidikan cinta alam banyak digunakan metode penyadaran, bimbingan dan praktek, karena dari harapan pemakaian metode ini anak didik dapat menguasai materi-materi yang diajarkan serta bisa mempraktekannya di lapangan sesuai dengan kapasitas yang dimilikinya bahwa nilai-nilai pendidikan agama Islam bisa melalui kegiatan cinta dan bahwasannya agama Islam memerintahkan kita agar senantiasa melakukan kegiatan cinta alam sebagai wujud pengabidan kita kepada Tuhan YME.

Berdasarkan pembuktian dengan melakukan pengolahan data deskriptif kualitatif. dengan demikiand ari pengujian di atas maka menunjukkan bahwa sejauh ini penanaman nila-nilai pendidikan agama Islam melalui kegiatan sinta alam Esspala SMU Negeri I Pabelan Kabupaten Semarang tahun 2007. yaitu : terdapat adanya nilai-nilai 
pendidikan agama Islam tentang wujud rasa syukur dan keimanan akan ciptaan Allah SWT. namun adanya juga faktor-faktor yang menjadi kendala dari Pembina dalam penanaman nilai-nilai pendidikan Islam pada anak didik Esspala SMU Negeri 1 Pabelan Kabupaten Semarang tahun 2007 karena keterbatasan wacana-wacana tentang lingkungan.

\section{Kesimpulan}

Dari hasil penelitian diketahui bahwa asumsi anak didik dalam memahami kegiatan cinta alam SMU Negeri I Pabelan Kabupaten Semarang sangatlah rendah. Pemahaman mereka mengikuti kegiatan cinta alam hanya sebatas untuk bersenang-senang saja. hal ini disebabkan oleh beberapa faktor yang salah satunya adalah dari kesadaran anak didik sendiri dalam pemaknaan kegiatan organisasi cinta alam dan tujuan keikut sertaannya yang sebatas untuk refresing dan pelarian dari keluarga, karena jauh dari orang tua.

Dari hasil penelitian diketahui bahwa penanaman nilai-nilai pendidikan agama Islam melalui kegiatan cinta alam SMU Negeri I Pabelan Kabupaten Semarang sangatlah terbatas dan hanya sekedar pemberian materi-materi tentang kegaitan adventure atau kepetualangan olahraga alam bebas, hal ini disebabkan karena, keterbatasan ilmu pengetahuan tentang nilai-nilai ajaran keagamaan melalui kegiatan cinta alam dan wacana-wacana tentang lingkungan hidup dari Pembina, faktor yang lainnya yaitu : latar belakang dari Pembina sendiri bukan dari organisasi pencinta alam atau dari Pembina belum pernah mengikuti 
pendidikan-pendidikan dasar tentang kepecintaalaman dan kepetualangan.

Dari hasil penelitian di lapangan bahwa, seberapa jauhkah penanamannilai-nilai pendidikan agama Islam pada anak didik melalui kegiatan cinta alam Esspala SMU Negeri I Pabelan Kabupaten Semarang tahun 2007 sangatlah rendah, hal ini disebabkan oleh faktor dari para Pembina sendiri dalam memahami akan makna-makna yang terkandung dalam kegiatan cinta alam yang ada di Esspala SMU Negeri I Pabelan Kabupaten Semarang, dan sejauh ini dari hasil analisis deskriptif kualitatif dari pengumpulan data yang diperoleh dari hasil di lapangan menunjukkan bahwa sejauh ini penanaman nilai-nilai pendidikan agama Islam pada anak didik melalui kegiatan cinta alam Esspala SMU Negeri I Pabelan Kabupaten Semarang tahun 2007 sangatlah rendah, seperti penerapan nilai keimanan pada anak didik dalam kegiatan cinta alam dan dalam penanaman nilai ibadah melalui kegiatan cinta alam.

\section{Daftar Pustaka}

Al-Buraey, Muhammad. 1986. Islam Landasan Alternative Adminitrasi Pembangunan. Jakarta: CV. Rajawali.

Al-Jamali, Muhammad Fadhil. 1986. Filsafat Pendidikan Dalam Islam. Surabaya: Bina Ilmu.

Al-Qardhawy, Yusuf. 1983. Iman dan Kehidupan. Jakarta: Bulan Bintang.

Departemen Pendidikan dan Kebudayaan. 1994. Kamus Besar Bahasa Indonesia. Jakarta: Balai Pustaka.

Maslikah. 2004. Harmonisasi Dan Humanisasi Lingkungan Hidup. Salatiga: Penerbit STAIN Press.

Nawawi, Hadari. 1993. Pendidikan dalam Islam. Surabaya: Al-Ikhlas. 
Prayitno, dkk. 1998. Pelayanan Bimbingan dan Konseling. Jakarta: PT Ikrar Mandiri Abadi.

Resosoedarmo, R. Soedjiran, Kuswata Kartawinata, Aprilani Soegiarto. 1985. Pengantar Ekologi. Bandung: Remadja Karya.

Soearjani, Moh., Rofiq Ahmad, Rozy Munir. 1987. Lingkungan Sumber Daya Alam dan Kependudukan Dalam Pembangunan. Jakarta: UIPress.

Sulaeman, Dadang. 1987. Dasar-Dasar Bimbingan dan Pengertian. Bandung: IKIP Bandung

Thaha, M. Chabib. 1996. Kapita Selekta Pendidikan Islam. Yogyakarta: Pustaka Pelajar.

Tim Dosen FIP - IKIP Malang. 1980. Pengatur Dasar-Dasar Kependidikan. Surabaya: Penerbit Usaha Nasional. 
Mudarrisa: Jurnal Kajian Pendidikan Islam, Vol. 7, No.1, Juni 2015: 117-146 